\title{
Habitat characteristics and odonate communities at selected sites used by Mortonagrion hirosei Asahina (Zygoptera: Coenagrionidae) in Hong Kong
}

\author{
D.J. Stanton ${ }^{1} \&$ J.A. Allcock ${ }^{2}$ \\ 1,2 Asia Ecological Consultants Ltd., 127 Commercial Centre, Palm Springs, Yuen Long, Hong Kong \\ Email: ${ }^{1}$ davidstanton@asiaecol.com.hk (corresponding author), ${ }^{2}$ jallcock@asiaecol.com.hk
}

Date of publication (online): 26 December 2011 Date of publication (print): 26 December 2011 ISSN 0974-7907 (online) | 0974-7893 (print)

Editor: Albert Orr

\section{Manuscript details:}

Ms \# 02891

Received 26 July 2011

Final received 08 November 2011

Finally accepted 17 November 2011

Citation: Stanton, D.J. \& J.A. Allcock (2011). Habitat characteristics and odonate communities at selected sites used by Mortonagrion hirosei Asahina (Zygoptera: Coenagrionidae) in Hong Kong. Journal of Threatened Taxa 3(12): 2242-2252

Copyright: ( D.J. Stanton \& J.A. Allcock 2011. Creative Commons Attribution 3.0 Unported License. JoTT allows unrestricted use of this article in any medium for non-profit purposes, reproduction and distribution by providing adequate credit to the authors and the source of publication.

Author Details: DAVID J. STANTON and JOHN A ALLCOCK are both professional ecologists and are both associates at Asia Ecological Consultants Ltd. based in Hong Kong. They conduct surveys and monitoring for a wide range of faunal groups mostly in Hong Kong and also overseas.

Author Contribution: DJS and JAA both participated in the design of the study, acquisition of data, analysis and interpretation of data, and drafting of the manuscript. Both read and approved the final manuscript. Both the authors have contributed equally to this paper.

Acknowledgements: The authors would like to thank Paul Leader and Graham Reels for their extensive comments and constructive advice on early drafts of this report. We would like to also thank three (anonymous) reviewers for providing critical reviews and greatly improving this manuscript. We would also like to thank Tony Nip for providing the local language abstract.

Asia Ecological Consultants Ltd

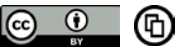

OPEN ACCESS | FREE DOWNLOAD
Abstract: Mortonagrion hirosei, a Near Threatened species, is a small damselfly recorded from several isolated sites across its entire range in eastern Asia. Previous research has indicated a strong affinity for brackish wetlands, including reedbeds and marshes, where potential predation or competition by other odonates is reduced. Results from surveys conducted in Hong Kong during 2009-2011 provide information on the habitat at a number of sites occupied by $M$. hirosei and report on the presence of populations in mangrove and mangrove-mosaic habitats as well as brackish marsh, often in association with a diversity of other odonates. Information is also provided on two previously unreported sites in Hong Kong. These new findings indicate that the species uses a greater diversity of habitats than the odonate-poor Phragmites reedbeds in which it has been well-studied in Japan, and consequently may be more widespread than previously supposed. Given that coastal habitats are threatened throughout its range, it is hoped this broader understanding of the species' habitat requirements will encourage others to explore other coastal sites and to aid in its conservation.

Keywords: Brackish wetlands, coastal habitat loss, Hong Kong, mangrove, Mortonagrion hirosei, odonates.

Chinese Abstract: 廣瀨妹蟌是一近危小型豆娘, 在其分佈範圍(東亞)，只能在數個獨 立地區發現。據文獻記載，此蟌多在蜻蛉目多樣性較低的咸淡水濕地棲息(如蘆葦床及咸 淡水沼澤), 而相信這樣的生境需求是要避免與其他蜻蛉目品種競爭或要減少被獵食的機 會。本研究於2009-2011年間在香港進行，發現此蟌只在香港數個地方出現(有兩個是未 記載過的新地點), 其生境包括紅樹林, 紅樹林沼澤, 及咸淡水沼澤, 而在這些生境亦常 發現其他蜻蛉目品種的蹤跡。在日本, 廣瀨妹蟌通常只在蜻蛉目多樣性極低的蘆葦床出 現; 但本研究顯示此品種能利用多種生境, 故其分佈有可能較以前估計的廣。在東亞, 沿岸生境不停被破壞, 我們希望本研究能增加對廣瀨妹蟌生境的認識, 從而制定正確的 調查與保育方案

\section{INTRODUCTION}

Mortonagrion hirosei is a small damselfly (Images 1 \& 2) occurring in coastal areas of eastern Asia including Japan, Hong Kong, Taiwan and Korea (Fig. 1). There is also an inland record from Guangdong, China. It is currently listed as Near Threatened in the IUCN Red List of Threatened Species (Wilson \& Reels 2011) because it is known from only a very small number of sites and there has been a decline in habitat area at the known Japanese sites. There is an ongoing loss of coastal habitats within the species' known and expected range in eastern Asia that presents the major threat to the species' survival.

Studies conducted in southern Japan found that $M$. hirose $i$ is extremely site-specific, mature adults moving on average only $3.3 \mathrm{~m}$ per day in the reedbed understorey; adults may not move more than $100 \mathrm{~m}$ in their entire life-time (Watanabe \& Mimura 2003, 2004; Mimura \& Watanabe 2006). The species is a weak flyer; it adopts a sit-and-wait tactic when searching for prey or mates, and adults do not leave the site where they emerge, 


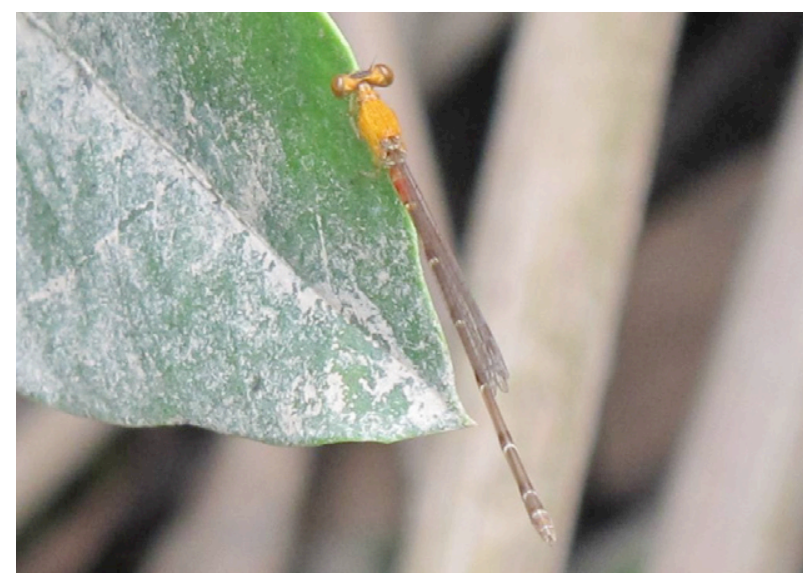

Image 1. Mortonagrion hirosei female - orange form

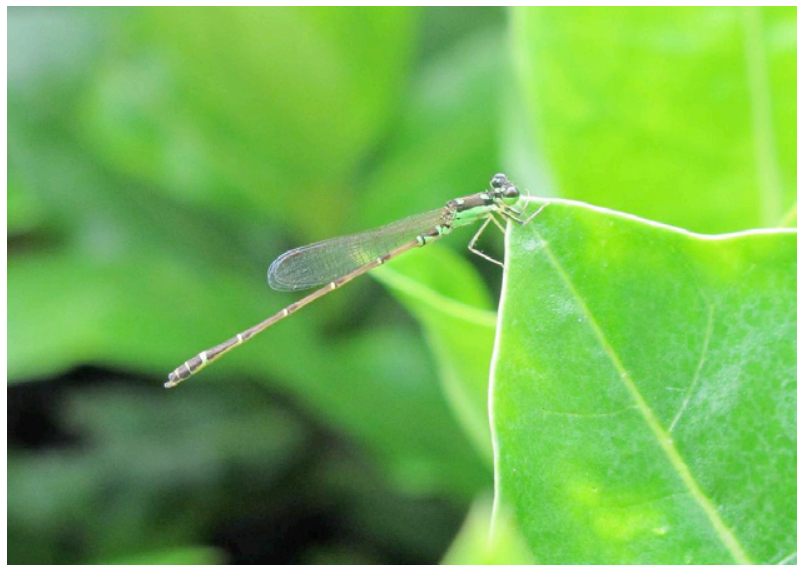

Image 2. Mortonagrion hirosei male

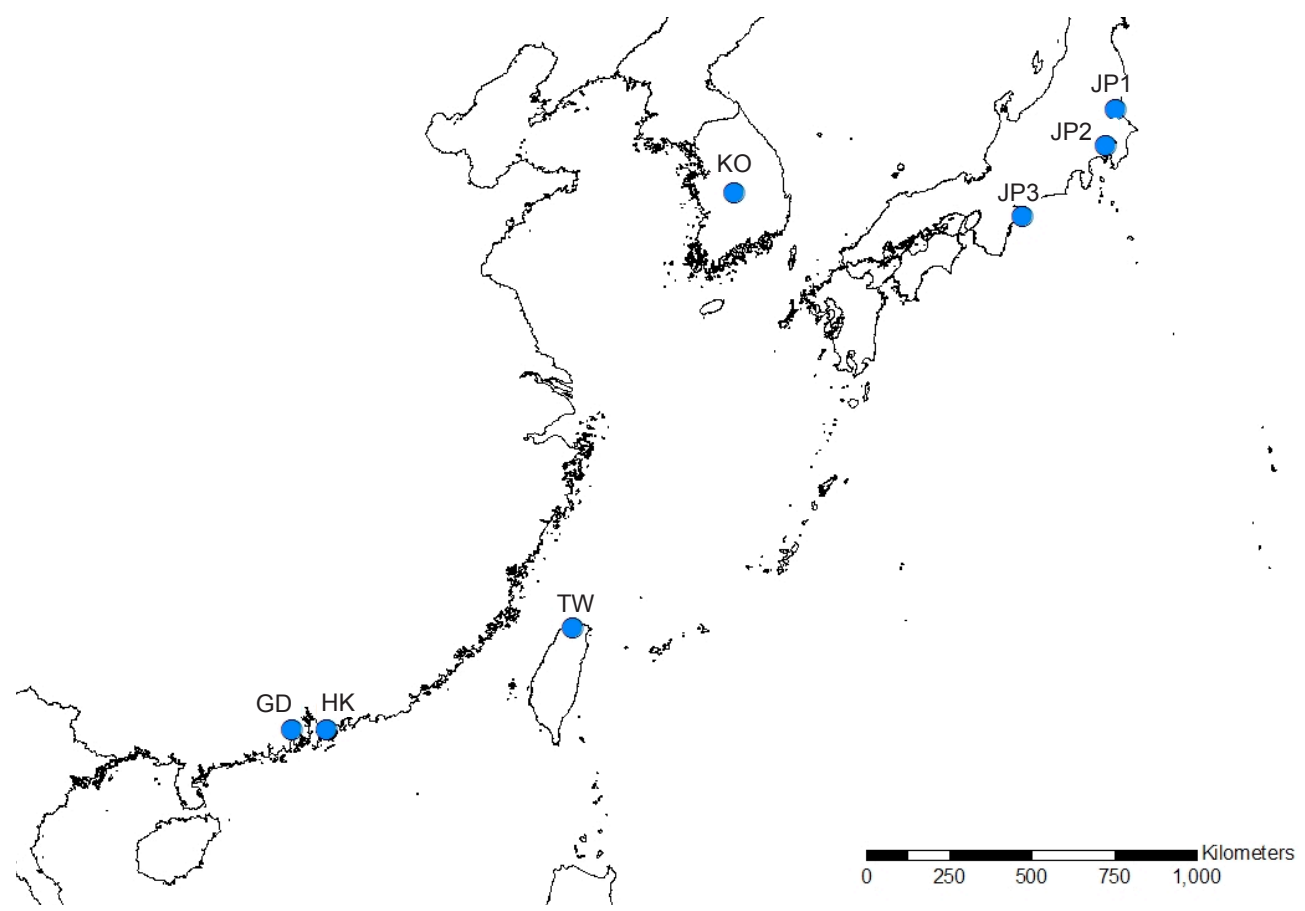

Figure 1. Known global distribution of Mortonagrion hirosei.

HK - Hong Kong; GD - Gutoushan, Guangdong, China; JP1 - Ibaraki Prefecture, Japan; JP2 - Sumida Ward, Tokyo, Japan; JP3 - Ise City, Mie Prefecture, Japan; KO - Korea (exact location unknown); TW - Wu Gu wetlands, Taipei, Taiwan

remaining in the reed community throughout their entire adult life (Watanabe \& Mimura 2003, 2004). Given this low dispersive mobility, the species cannot easily disperse to new locations and the long-term protection of the species relies upon the protection of known locations and/or provision of suitable alternative habitat within this small dispersal range.

Wilson \& Reels (2011) recommend that a more comprehensive understanding of habitat requirements is important for conservation of the species. Preliminary observations by the authors in Hong Kong suggested that this species actually uses a wider range of habitats than has been described at the well-studied sites in Japan. This study aims to document habitats present at a variety of sites in Hong Kong and investigate whether sites used by $M$. hirosei generally have a depauperate odonate community, as has previously been suggested. Such observations from Hong Kong may be applicable to potential sites elsewhere in eastern Asia. 


\section{Distribution and habitat selection at known sites}

The species was described in 1972 based on specimens collected in brackish Phragmites reedbeds in Hinuma, Ibraraki in Japan. It was thought to be endemic to Japan until another population was discovered at Mai Po Marshes Nature Reserve in Hong Kong in 1991 (Reels 1994; Wilson 1994; Wilson 1995). This discovery provided additional evidence that brackish reedbed is an important habitat for the species. Subsequently the species has since been found at other locations in Hong Kong, including Sai Sha, Double Island, Hong Kong Wetland Park (Tin Shui Wai), Luk Keng, Mai Po Marshes, Nam Chung, Sam A Tsuen and Sha Po (Wilson 1997; Wilson 2004; Tam et al. 2008).

It was first recorded in Taiwan in 2005, at a coastal wetland in $\mathrm{Wu} \mathrm{Gu}$ near Taipei (Lin \& Chen 2006), and has also been reported from Korea in paddy fields between 1997 and 2006 (Bang et al. 2009). Other than Hong Kong and Korea, M. hirosei has not been recorded along the coast of mainland eastern Asia, but it is likely that other populations remain undiscovered in southern and eastern coastal China. There is also a single 2005 record from an inland site in Gutoushan, Guangdong, China (Wilson \& Reels 2011).

Phragmites reedbeds form an important component of the habitat at the known sites on the east coast of Honshu in Japan, and Watanabe et al. (2008) state that "Mortonagrion hirosei ... inhabits the understory of dense reed communities". Conservation of the species in Japan has therefore mainly involved the protection of brackish reedbeds as well as the creation of additional brackish reedbed habitat. Watanabe (2007), Watanabe et al. (2008), Iwata \& Watanabe (2009) and Teramoto $\&$ Watanabe (2009) discuss the colonisation of these created reedbeds by $M$. hirosei.

IUCN gives the main habitat association as brackish marsh, including mangrove (Wilson \& Reels 2011); the specific addition of mangrove in the IUCN assessment was based upon our observations of $M$. hirosei in the Mai Po Marshes intertidal mangrove in 2008 (G.T. Reels pers. comm.). At Luk Keng in Hong Kong, M. hirosei was reported to occur in water chestnut Eleocharis dulcis and Phragmites reeds, but was three times more abundant in the latter habitat (Cheung 2008). The presence of an inland site in Guangdong, China has recently been reported in Wilson \& Reels (2011) but details of the habitats have not been published at the time of writing.

\section{Association with other odonates}

Because of its small size, $M$. hirosei is at risk of predation from other odonate species in both adult and larval stages (Lin \& Chen 2006; Matsu'ura \& Watanabe 2006; Iwata \& Watanabe 2009). This risk may be aggravated by the adults' weak flight and bright coloration (Watanabe \& Mimura 2003), thus the presence of certain other odonate species might be expected to influence the presence and relative abundance of $M$. hirosei at a given site. Indeed, Iwata \& Watanabe (2009) have suggested that predation pressure, particularly from Ischnura senegalensis, may be partly responsible for the importance of brackish reedbeds as a habitat, as the reeds provide cover for adults and the brackish water is unsuitable breeding habitat for most potential predators.

\section{METHODS}

\section{Observations of habitat characteristics and odonate communities at selected sites in Hong Kong}

The following paragraphs describe the habitat characteristics and odonate assemblages at some of these locations, including Mai Po Marshes, Sam A Tsuen and Sai Sha (Fig. 2). Similar details are also provided for four locations which were not identified by Tam et al. (2008). These observations are based upon site visits conducted between May 2009 and June 2011. The intention of these visits was to document the abundance of adult and teneral $M$. hirosei, the habitat present (including plant species present) and the odonate community at each location. All other odonates seen during survey were recorded. These species lists are not exhaustive and it should be noted that other species may also be present. Any of the species recorded may prey on or compete with $M$. hirosei, but to our knowledge predation has only been observed by I. senegalensis (Watanabe 2007; Watanabe et al. 2008; Iwata \& Watanabe 2009) and Ceriagrion auranticum (G.T. Reels pers. comm.). No observations of larvae were made. Visits did not follow predetermined transects, and the frequency and duration of visits varied between locations according to accessibility and the area covered. Maximum counts in the text are not directly comparable between 


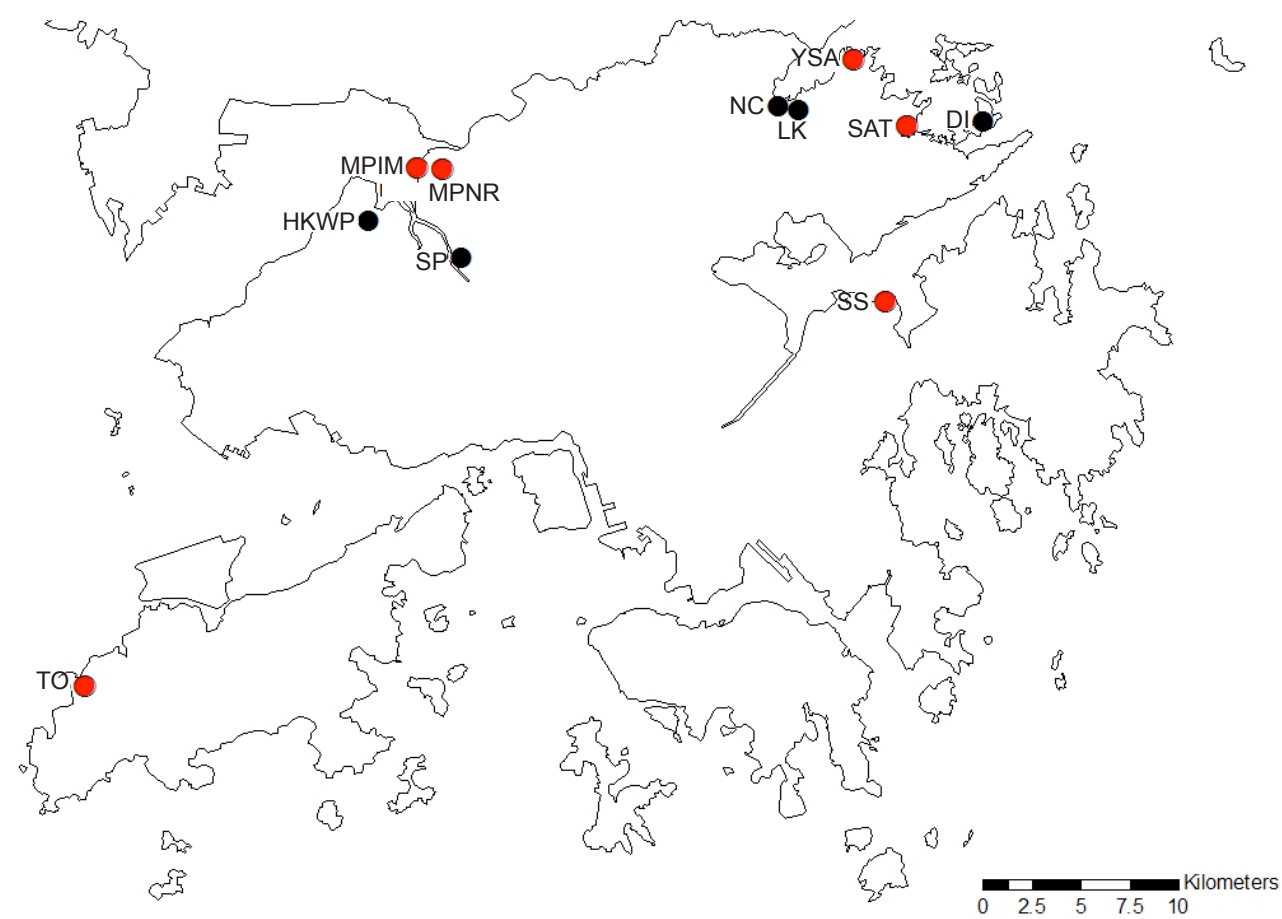

Figure 2. Distribution of Mortonagrion hirosei in Hong Kong.

MPNR - Mai Po Marshes Nature Reserve; MPIM - Mai Po Marshes Intertidal Mangrove; SAT - Sam A Tsuen; SS - Sai Sha; TO - Tai O; YSA - Yung Shue Au; DI - Double Island; HKWP - Hong Kong Wetland Park; SP - Sha Po; LK - Luk Keng; NC - Nam Chung. Sites marked in red were surveyed as part of this study.

sites, but are included to give an impression of overall $M$. hirosei numbers at each site.

Nomenclature for odonates follows Wilson (2004) and for vegetation, follows the arrangement used by the Hong Kong Herbarium (http://www.hkherbarium. net/herbarium/frame.html).

\section{RESULTS}

The following paragraphs describe the findings at the six locations surveyed between May 2009 and June 2011 and results are summarised in Table 1.

\section{Mai Po Marshes Nature Reserve - Gei wai}

Mai Po Marshes Nature Reserve (MPNR) (22029.7'N \& $\left.114^{0} 2.5^{\prime} \mathrm{E}\right)$ comprises a series of brackish "gei wai" - ponds operated in a traditional manner for the culture of shrimps (usually Metapenaeus ensis). Commercial shrimp culture no longer occurs within these gei wai, and the pond operation is now managed by WWF-Hong Kong (WWF-HK) for the benefit of wildlife. Gei wai are connected to the sea and are periodically drained and flooded with sea water through sluice gates, creating brackish water conditions. Most of the gei wai at MPNR contain Phragmites australis reedbeds and/or stands of mangroves. To the seaward side of the reserve is an area of intertidal mangroves, adjoining extensive intertidal mudflats in Deep Bay. MPNR is included in the core of the Mai Po Inner Deep Bay Ramsar Site.

The first Hong Kong records of $M$. hirosei came from the MPNR gei wai in 1991, when individuals were caught by Malaise traps set in one of the Phragmites reedbeds (Reels 1994). This study found M. hirosei to be one of the most numerous species trapped in these Malaise traps, suggesting a high density in this habitat. The reedbeds used for Malaise trapping were visited regularly during the 2009-10 visits, and no $M$. hirosei were recorded. Malaise trapping was also conducted by WWF-HK at the same site in 2009-10, but M. hirosei was not recorded (Katherine K.S. Leung in litt.). The nature of this reedbed has changed since 1991; notably substrate levels have been lowered in much of the reedbed to prevent colonisation of terrestrial vegetation. Other odonates observed in 2009-2010 at this brackish Phragmites reedbed included $C$. auranticum, Paracercion melanotum, I. senegalensis, 
Table 1. Summary of vegetation and Odonata at locations surveyed in 2009-2011

\begin{tabular}{|c|c|c|c|c|}
\hline Location & Habitats & Dominant Vegetation & $\begin{array}{l}\text { Max. count } \\
\text { of flying } \\
\text { M. hirosei } \\
\text { (adults and } \\
\text { teneral) }\end{array}$ & $\begin{array}{l}\text { Other Odonata recorded (known } \\
\text { predators in bold) }\end{array}$ \\
\hline $\begin{array}{l}\text { Mai Po Marshes Nature } \\
\text { Reserve (MPNR) } \\
\left(22^{\circ} 29.7^{\prime} \mathrm{N} \& 114^{0} 2.5^{\prime} \mathrm{E}\right)\end{array}$ & $\begin{array}{l}\text { Brackish gei wai (\#8) with } \\
\text { Phragmites Reedbed, } \\
\text { Open Water }\end{array}$ & Phragmites australis & $\begin{array}{l}0 \\
\text { (single adult } \\
\text { observed } \\
\text { in brackish } \\
\text { grasses in } \\
\text { another gei } \\
\text { wai) }\end{array}$ & $\begin{array}{l}\text { Ceriagrion auranticum, } \\
\text { Paracercion melanotum, Ischnura } \\
\text { senegalensis, Anax parthenope, } \\
\text { Brachythemis contaminata, } \\
\text { Brachydiplax chalybea, Orthetrum } \\
\text { sabina, Pantala flavescens and } \\
\text { Tholymis tillarga. }\end{array}$ \\
\hline $\begin{array}{l}\text { Mai Po Marshes - } \\
\text { Intertidal Mangrove } \\
\left(22^{\circ} 29.7^{\prime} \mathrm{N} \& 114^{0} 1.9^{\prime} \mathrm{E}\right)\end{array}$ & Intertidal Mangroves & $\begin{array}{l}\text { Kandelia obovata, Acanthus } \\
\text { ilicifolius, Aegiceras } \\
\text { comiculatum, Avicennia } \\
\text { marina, Bruguiera gymnorrhiza, } \\
\text { Excoecaria agallocha and } \\
\text { Heritiera littoralis }\end{array}$ & 50 & $\begin{array}{l}\text { I. senegalensis, P. flavescens, } \\
\text { O. sabina, Rhyothemis variegata, } \\
\text { Pseudothemis zonata and } \\
\text { Trithemis aurora. }\end{array}$ \\
\hline $\begin{array}{l}\text { Sai Sha } \\
\left(22^{0} 26.0^{\prime} N \& 114^{0} 15.7^{\prime} E\right)\end{array}$ & $\begin{array}{l}\text { Shallow, brackish pools } \\
\text { established in the shingle } \\
\text { of the supralittoral shore } \\
\text { amongst the backshore } \\
\text { vegetation. }\end{array}$ & $\begin{array}{l}\text { K. obovata, Hibiscus tiliaceus, } \\
\text { Zoysia matrella and Cynodon } \\
\text { dactylon }\end{array}$ & 27 & $\begin{array}{l}\text { C. auranticum, Acisoma } \\
\text { panorpoides, Orthetrum Iuzonicum } \\
\text { and Orthetrum poecilops. }\end{array}$ \\
\hline $\begin{array}{l}\text { Sam A Tsuen } \\
\left(22^{\circ} 30.9^{\prime} \mathrm{N} \& 114^{0} 16.3^{\prime} \mathrm{E}\right)\end{array}$ & $\begin{array}{l}\text { Brackish marsh derived } \\
\text { from abandoned paddies }\end{array}$ & $\begin{array}{l}\text { Acrostichum aureum, Cyperus } \\
\text { spp. }\end{array}$ & 3 & $\begin{array}{l}\text { Agriocnemis femina, C. } \\
\text { auranticum, I. senegalensis, } A . \\
\text { panorpoides, Diplacodes trivialis, } \\
\text { Neurothemis tullia, O. sabina and } \\
\text { P. flavescens }\end{array}$ \\
\hline $\begin{array}{l}\text { Tai O } \\
\left(22^{0} 15.4^{\prime} N \& 113^{0} 51.9^{\prime} \mathrm{E}\right)\end{array}$ & $\begin{array}{l}\text { Mangrove, Brackish } \\
\text { Marsh, deep brackish } \\
\text { pools }\end{array}$ & $\begin{array}{l}\text { A. ilicifolius, } A \text {. corniculatum, } A \text {. } \\
\text { marina, K. obovata, Sporobolus } \\
\text { virginicus }\end{array}$ & 2 & $\begin{array}{l}\text { Agriocnemis femina, Cercion } \\
\text { melanotum, C. auranticum, } \\
\text { I. senegalensis, Onychargia } \\
\text { atrocyana, Anax guttatus, } \\
\text { A. panorpoides B. chalybea, } \\
\text { B.contaminata, Crocothemis } \\
\text { servilia, Diplacodes trivialis, } \\
\text { Macrodiplax cora, Neurothemis } \\
\text { tullia, Orthetrum chrysis, O. } \\
\text { luzonicum, Orthetrum pruinosum } \\
\text { O. sabina, P. flavescens and T. } \\
\text { tillarga. }\end{array}$ \\
\hline $\begin{array}{l}\text { Yung Shue Au } \\
\left(22^{0} 32.7^{\prime} \mathrm{N} \& 114^{0} 14.8^{\prime} \mathrm{E}\right)\end{array}$ & Short grass and sedge & $\begin{array}{l}\text { Short grass and sedge } \\
\text { (unidentified) }\end{array}$ & 7 & $\begin{array}{l}\text { C. auranticum, I. senegalensis, } \\
\text { N. tullia and O. sabina. }\end{array}$ \\
\hline
\end{tabular}

Anax parthenope, Brachythemis contaminata, Brachydiplax chalybea, Orthetrum sabina, Pantala flavescens and Tholymis tillarga.

Elsewhere in MPNR, the species has also been recorded from vegetated bunds of both freshwater and brackish ponds and intertidal mangroves (WWF-HK 2010). The only individual recorded in the gei wai of MPNR during the 2009-10 visits was a single male seen in May 2010, on emergent vegetation composed of individual Phragmites stems and mats of grasses on the edge of a deep water channel. This vegetation was not particularly tall or structurally dense and this individual was in the open, perched on semi-submerged vegetation. Much of the potentially suitable habitat in

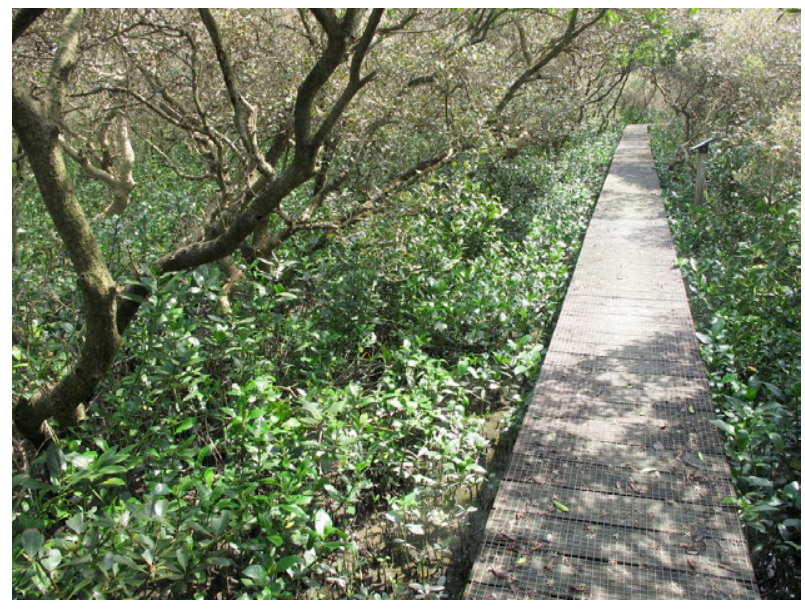

Image 3. Mai Po Intertidal Mangroves

populations remain in the gei wai that were not visited in 2009-10. No M. hirosei were observed but it is possible that 


\section{Mai Po Marshes - Intertidal Mangrove (Image 3)}

A strip of mangroves $\left(22^{0} 29.7^{\prime} \mathrm{N} \& 114^{0} 1.9^{\prime} \mathrm{E}\right)$ varying between 500 and $1000 \mathrm{~m}$ wide along the northern boundary of the Reserve, separates the gei wai in MPNR from the open intertidal mudflats of Inner Deep Bay. Dominant mangrove species include Kandelia obovata, Acanthus ilicifolius, Aegiceras corniculatum, Avicennia marina, Bruguiera gymnorrhiza, Excoecaria agallocha and Heritiera littoralis (WWF-HK2006). This mangrove community continues around the landward side of the intertidal mudflats in the whole of Inner Deep Bay, but is difficult to access except through a network of floating and fixed boardwalks extending from MPNR. Although the intertidal mangroves are immediately adjacent to the gei wai at MPNR, these are treated here as a different location because the habitat characteristics differ significantly from those present in the gei wai. The low dispersive ability of $M$. hirosei means that individuals would not be able to disperse far into the intertidal mangrove from known populations in the gei wai.

Ecological surveys in the intertidal mangroves during 2005-06 to assess the impacts of an extension to the existing boardwalk access did not record $M$. hirosei (WWF-HK 2006). The species was first observed in this location by the authors in 2008, and has also been recorded by WWF-HK (WWF-HK 2010). The maximum counts during the 2009-11 visits were 32 in July 2009 and 50 on 14 May 2011. Observations have been made on both rising and falling tides, when bare mud is revealed at the base of mangroves.

The intertidal mangroves do not contain any significant-sized stands of Phragmites reedbeds, but small stands (up to approximately $2 \mathrm{~m}^{2}$ ) of reeds are patchily located on the landward side of the mangroves. Most observations of $M$. hirosei in the intertidal mangroves are distant from any Phragmites reedbeds, with individuals observed up to $700 \mathrm{~m}$ from the nearest reedbeds (located within the gei wai). This is seven times the estimated maximum dispersal distance of an individual $M$. hirosei, suggesting that individuals seen cannot have come from the Phragmites reedbeds. Within the intertidal mangrove, most individuals were observed either at the interface between taller mangrove and shrubbier A. ilicifolius, or where openings in the tall mangrove canopy create areas of dappled sunlight, often perching on mangrove pneumatophores (Image

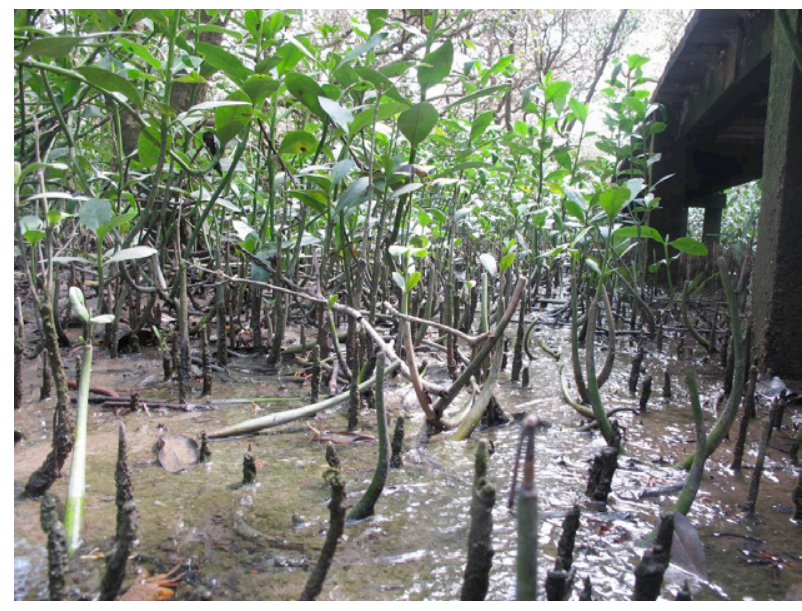

Image 4. Mai Po intertidal mangroves- pneumatophores

4) or stems up to approximately $0.2 \mathrm{~m}$ from the exposed substrate. Individuals are not evenly distributed across the habitat but seem to be rather patchily distributed, particularly in areas where uneven substrate ensures that shallow water remains during low tide and where there is a higher density of pneumatophores. Coupling has often been observed in this habitat, indicating that egg laying and larval development also take place in the intertidal mangrove system.

Numbers of other odonates are generally low in these intertidal mangroves. Other odonate species recorded along these boardwalks on the same dates as observations of $M$. hirosei included I. senegalensis, P. flavescens, O. sabina, Rhyothemis variegata, Pseudothemis zonata and Trithemis aurora. Small numbers of $I$. senegalensis (no more than five on any visit) were recorded in similar habitats to $M$. hirosei, but the other odonate species were observed in open areas along creeks or at the edge of the taller mangrove stands.

\section{Sai Sha}

Small numbers of $M$. hirose $i$ were recorded from a $200 \mathrm{~m}$ section of boulder-strewn coastline of the Sai Sha Peninsula $\left(22^{\circ} 26.0^{\prime} \mathrm{N} \& 114^{0} 15.7^{\prime} \mathrm{E}\right)$ between May and October 2009 and subsequently in 2010 and 2011. These individuals were seen around shallow, brackish pools established in the shingle of the supralittoral shore amongst the backshore vegetation (Image 5). The pools, no more than $0.2 \mathrm{~m}$ deep, are thought to have been created from a combination of exceptionally high tides, sea spray, wet season rainfall and run-off from adjacent abandoned paddies. 


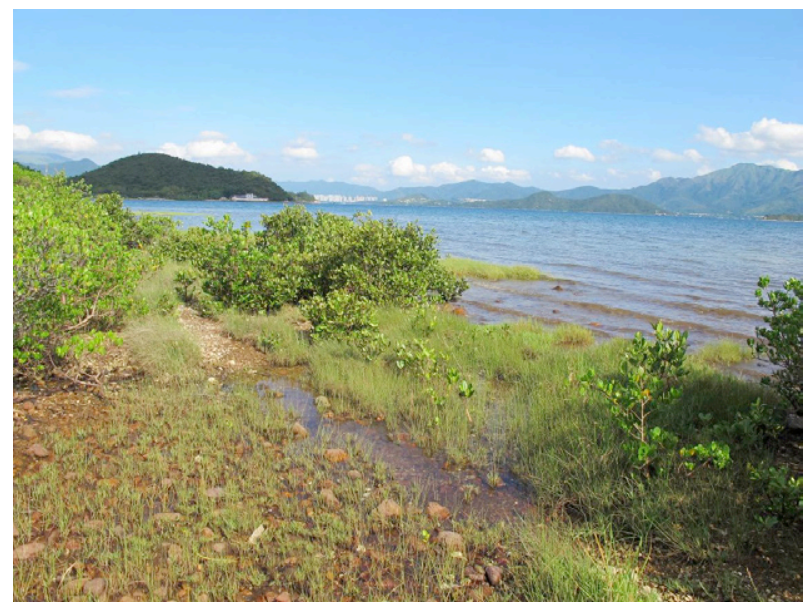

Image 5. Sai Sha

Vegetation surrounding the pools is composed of shrub mangroves (K. obovata), coastal trees (Hibiscus tiliaceus) and grasses such as Zoysia matrella and Cynodon dactylon. Long-abandoned paddies on the landward side have developed into marsh dominated by grassy vegetation but no $M$. hirosei were observed there. No Phragmites reeds are known to occur in the area. This location is situated approximately $9 \mathrm{~km}$ from the closest known M. hirosei population (at Sam A Tsuen in the northeast New Territories).

Adult and teneral individuals of $M$. hirosei were regularly recorded during 2009-11 visits perched up to $0.2 \mathrm{~m}$ from the ground on bare branches of low shrubby mangroves or on the stems of grasses around the fringes of the brackish pools. The maximum number of individuals recorded was 27 , including both adults and tenerals, during June 2011. Tandem pairs have also been observed at this location. Other odonates were also regularly observed in the coastal vegetation, including C. auranticum, Acisoma panorpoides, Orthetrum luzonicum and Orthetrum poecilops. Orthetrum poecilops is listed by IUCN as Vulnerable (Wilson 2009) and is associated with brackish water habitats, especially mangroves.

\section{Sam A Tsuen}

Observations of $M$. hirosei at Sam A Tsuen $\left(22^{0} 30.9^{\prime} \mathrm{N} \& 114^{0} 16.3^{\prime} \mathrm{E}\right)$ came from an area of brackish marsh derived from abandoned paddies. This location was visited less frequently than the others (three visits during 2009-11), and M. hirosei was observed only once in August 2009. Individuals of $M$. hirosei observed at the site were seen flying in an area of grasses up to $0.1 \mathrm{~m}$ tall, with scattered small individuals of the mangrove-associated fern Acrostichum aureum. Other parts of the marsh contain extensive areas of grasses and sedges Cyperus spp. up to $0.3 \mathrm{~m}$ high, but no $M$. hirosei were observed in this vegetation. Water within the marsh was mostly shallow (less than $0.05 \mathrm{~m})$ during visits, with a deeper channel $(0.3 \mathrm{~m})$ draining through the marsh. The extent and frequency of flooding at high tide is not known. A fairly open stand of mangroves (including $K$. obovata, A. marina, E. agallocha and $A$. corniculatum) is present on the seaward side of the marsh, approximately $100 \mathrm{~m}$ from the location of the observations, but no Phragmites reeds are known at the site.

Other odonates recorded at the site were Agriocnemis femina, C. auranticum, I. senegalensis, A. panorpoides, Diplacodes trivialis, Neurothemis tullia, $O$. sabina and P. flavescens; these species were present generally in low numbers (up to five individuals of each species recorded), with the exception of $P$. flavescens, which has been was seen in large gatherings (up to 70 individuals) on the fringes of adjacent woodland during surveys.

\section{Tai $\mathbf{O}$}

In May 2009, another population of $M$. hirosei was discovered in Tai O, Lantau $\left(22^{0} 15.4^{\prime} \mathrm{N}\right.$ \& $\left.113^{0} 51.9^{\prime} \mathrm{E}\right)$. This is the first known record for Lantau Island and is located $29 \mathrm{~km}$ southwest of the nearest known population in Hong Kong. This is an area of former salt-pans which have been abandoned and are now subject to regular tidal inundations. Vegetative

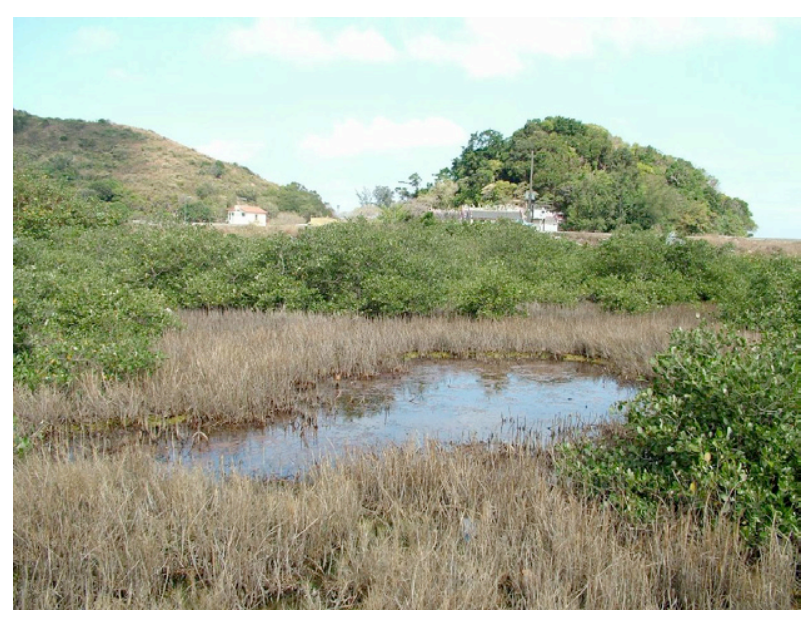

Image 6. Tai O 
succession on these salt-pans has created a mosaic of microhabitats, including brackish marsh, deeper brackish pools and mangrove (Image 6). Low numbers of $M$. hirosei (up to two individuals) were recorded on visits in 2009-10. Most sightings were made in an area permanently under water of varying depths $(0.1-0.5 \mathrm{~m})$, often in the shade of larger mangrove specimens (A. ilicifolius, A. corniculatum, A. marina and $K$. obovata). Individuals observed were perched either on mangrove pneumatophores or on grasses (e.g. Sporobolus virginicus), at about $0.2 \mathrm{~m}$ from the water's surface, usually in the shade of a mangrove shrub. Whilst Phragmites is present in the area, it does not form large stands or reedbeds, but is interspersed within the vegetation of the brackish marsh, approximately $50 \mathrm{~m}$ from the area where $M$. hirosei was recorded.

Nineteen other species of dragonfly were recorded near the perching locations of $M$. hirosei including high numbers of $I$. senegalensis $(100+$ during each visit), the most commonly occurring odonate at the site, along with moderate numbers of $O$. sabina and D. trivialis.

\section{Yung Shue Au}

The most recently discovered population of $M$. hirosei is at Yung Shue Au $\left(22^{0} 32.7^{\prime} \mathrm{N} \& 114^{0} 14.8^{\prime} \mathrm{E}\right)$ on the northeastern coastline of Hong Kong SAR in July 2011. Seven individuals were found at this site, occupying habitat similar to that observed at Sam A Tsuen, with an area of short grass and sedge (up to $0.1 \mathrm{~m}$ in height) which was inundated at high tide (Image 7). This population is located approximately

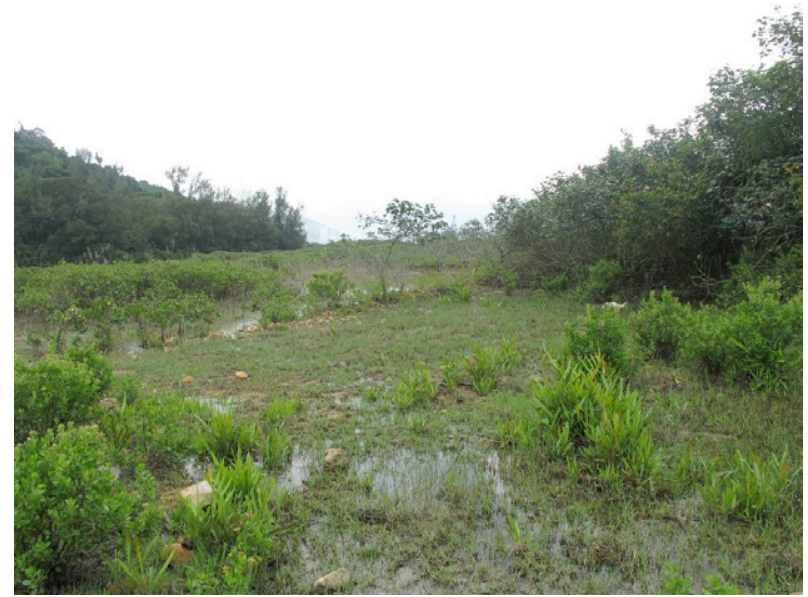

Image 7.Yung Shue Au
$3.9 \mathrm{~km}$ from the nearest known sites, at Sam A Tsuen and Luk Keng. Other odonate species present were $C$. auranticum, $I$. senegalensis, $N$. tullia and $O$. sabina.

\section{DISCUSSION AND CONCLUSIONS}

\section{Habitat requirements of $M$. hirosei}

Until recently Phragmites reedbeds were considered to be the primary habitat for this species. While Phragmites reedbed is an important habitat at some Hong Kong sites, the observations on the 200911 surveys indicate that at some locations in Hong Kong Phragmites is not an important component of the habitat, and may not even be present. Habitats at most locations visited for this study were dominated by grasses and/or mangroves, and the species was recorded in pure mangrove stands in Inner Deep Bay, several hundred metres from the nearest reedbed or marsh habitat. Considering the weak flight of the species, the distance of these observations from the nearest reedbed or marsh suggest that $M$. hirosei breeds in mangrove habitats in Hong Kong. This conclusion is strengthened by the observation of tandem pairs in the Mai Po Marshes intertidal mangroves. Wilson \& Reels (2011) note that, despite the presence of adults, larvae have never been recorded in mangrove habitats. Surveys for larvae or exuviae were not conducted at the sites studied, however, and therefore successful breeding in mangrove habitats remains unproven. Larval studies of mangrove and other habitats would provide further understanding on the habitat requirements of this species.

Hong Kong is at the southern end of the known global distribution of $M$. hirosei, and mangroves are to be found on much of the intertidal soft shore. Mangrove diversity and abundance is much reduced in more northern latitudes (Lee 2002) and in Japan mangroves are mostly limited to the southernmost prefecture of Okinawa (ISME 2010). The known sites for $M$. hirose $i$ are situated on the east of Honshu, where mangrove does not occur. Reedbed may be the dominant vegetative community at these latitudes, explaining the apparent preference of $M$. hirosei for this habitat. Thus latitudinal and climatic differences may ultimately account for the difference in observed habitat preferences between Hong Kong and Japan.

The most important factor influencing the 
distribution of M. hirosei in Hong Kong appears to be the hydrology of the site. All locations visited at which $M$. hirosei was recorded contain shallow brackish water, generally less than $0.2 \mathrm{~m}$ deep. The site with deepest permanent water (at Tai O) contained water up to $0.5 \mathrm{~m}$ deep. Deeper water may be experienced at high tide in some locations (for example in the Mai Po Marshes intertidal mangrove) but for most of the time the water does not reach this depth. No Hong Kong locations have yet been discovered at which only fresh water is present; $M$. hirosei has been reported at MPNR on the bunds of freshwater ponds (WWF-HK 2010), but the individuals involved may have strayed from nearby gei wai.

Vegetation structure may also be important in determining the suitability of a habitat. The species is known to use a sit-and-wait strategy when searching for prey or mates, and Watanabe \& Mimura (2003, 2004) report that $M$. hirosei are often recorded perching at an average height of about $20 \mathrm{~cm}$ above the water or the ground surface within the reedbed site studied. Similar behaviour was observed in all habitats during visits in 2009-11, with individuals observed perched on mangrove pneumatophores, grass stems or the lower branches of individual mangrove plants at a similar height.

\section{Relationships with other odonates}

In Japan, M. hirosei occurs in dense, brackish reedbeds where few other odonates occur (Watanabe \& Mimura 2003) and is susceptible to predation in both adult and larval form by other odonates, particularly $I$. senegalensis (Lin \& Chen 2006; Watanabe \& Matsu'ura 2006; Watanabe et al. 2008, Iwata \& Watanabe 2009).

At the Hong Kong locations visited during this study, M. hirosei was sometimes present in habitats with a moderate diversity and abundance of other odonates, both Zygoptera and Anisoptera, which could be potential predators. These include I. senegalensis, which was observed at all locations in high numbers. The 1991 study of Phragmites reedbed at Mai Po, which resulted in the first records of $M$. hirosei in the territory, also recorded a total of 10 odonate species from Malaise trapping (Reels 1994), and the true abundance may have been underestimated in this study because Malaise trapping tends to favour smaller, weaker flying odonates such as damselflies (Zygoptera) and underrepresent larger dragonflies (Anisoptera) (Glotzhober
\& Riggs 1998). Whilst it is acknowledged that other faunal groups could potentially predate the various life stages of M. hirosei, this has not been investigated.

Although M. hirosei populations in Hong Kong are apparently able to survive in the presence of potential predators, this predation may lead to lower population densities. High densities of this species have been reported in reedbeds in Japan, for example 22 adults per $\mathrm{m}^{2}$ as reported by Teramato \& Watanabe (2009) and comparable numbers by Watanabe \& Mimura (2003, 2004) and Watanabe et al. (2008). Although systematic studies of population densities were not part of this study, it was clear that overall numbers at some Hong Kong sites were significantly lower than those reported from Japan. Densities were lowest in habitats which also supported a higher abundance of other odonate species which may indicate that, while $M$. hirosei is tolerant of the presence of other species, these may limit the overall population, either by predation as suggested by Watanabe \& Mimura (2003) or through competition for resources.

\section{Potential populations elsewhere in eastern Asia}

One of the recommendations from IUCN is that the coastal breeding sites of this damselfly should be protected (Wilson 2006; Wilson \& Reels 2011). For this to occur, it is important that these sites are identified. With a known global distribution including Japan, Taiwan, Korea, and southern China, it can be assumed that this species is likely to be under-recorded along coastal areas of southern and eastern China. These known sites are separated by hundreds of kilometres of coastline or sea, and it would appear unlikely that such a weak-flying species would be able to readily colonise such widely-separated locations. When compared with Hong Kong and Japan, the Chinese coast has historically had relatively few observers recording odonates and the small size and biology of M. hirosei (including its weak flight and sit-and-wait foraging strategy) make the species easy to overlook. Misconceptions about its habitat requirements, especially the lack of awareness of mangrove as a potential habitat in the southern part of its range, may also have contributed to the species being overlooked at other sites in eastern Asia. Searches of coastal marsh and mangroves along the coastline of southern and eastern China may result in the discovery of more populations. The presence of other odonates which 
may be potential predators or competitors clearly does not preclude the survival of $M$. hirosei.

\section{Conservation and threats to global populations}

Throughout eastern Asia, coastal habitats are under extensive pressure for development and reclamation (Lin \& Chen 2006; Wilson 2006; WWF-HK 2010). In Japan, the extent of reedbeds has been substantially reduced by river alterations and the destruction of wetlands (Watanabe \& Mimura 2003). Coastal habitat in China is similarly being lost to city development, reclamation and dam construction (WWF-HK 2010), and the same is happening in Korea (Cho 2007). For example, in coastal Shenzhen, adjacent to the species' Hong Kong stronghold at Mai Po, there has been significant coastal habitat loss in the past 20 years through development and reclamation ( $\mathrm{Ni} \&$ Qin 2003). Populations of $M$. hirosei throughout easterm Asia may be declining and becoming increasingly isolated as coastal habitat is lost.

Habitat loss could also occur indirectly through natural processes such as sedimentation. Mudflat levels in Inner Deep Bay, where the species has its stronghold in Hong Kong, have risen by $0.3 \mathrm{~m}$ since the 1980s (WWF-HK 2006). Continued sedimentation may eventually prevent land from flooding at high tide, resulting in loss of intertidal habitats. Local extinctions may result from highly localised events such as extreme high tides washing through a small area of suitable habitat (for example at Sai Sha, where apparently only a small population is present in a narrow strip of habitat along the coast) or through changes in predation pressure. The isolation of populations as a result of coastal development, combined with the weak flight ability of the species, may mean that suitable sites cannot be recolonised once the population has been lost by stochastic events. At a larger scale, populations of a whole region may be at risk from events such as the devastating tsunami that struck Japan during March 2011.

Many of the Hong Kong sites are isolated by both developed areas and physical geography, and have few ecological linkages suitable for a weakflying species to exploit. Protection of known sites is therefore important, so that these can ensure the continued survival of the species. Currently only four of the known locations in Hong Kong are protected by legislation; at Mai Po Marshes Nature Reserve (including the intertidal mangroves of Inner Deep Bay), Hong Kong Wetland Park, Double Island and Luk Keng. Other sites are on land that may be at risk from development and/or neglect. Suitable habitat management would also be beneficial in providing increased habitat area or providing corridors to link populations. In Japan, research projects are being conducted to look at reedbed re-establishment programmes and the maintainence of dense reedbed communities in order to preserve this species, by reducing habitat loss and fragmentation (Watanabe et al. 2008; Iwata \& Watanabe 2009; Teramoto \& Watanabe 2009). Research so far has shown that the species is able to readily colonise newly created habitat if this is within the small dispersal range (Watanabe et al. 2008; Iwata \& Watanabe 2009; Teramoto \& Watanabe 2009). Habitat management at Mai Po Marshes and Hong Kong Wetland Park may permit the enhancement of habitats in these locations, but at present no other known sites in Hong Kong receive active habitat management.

\section{REFERENCES}

Bang, H.S, M.S. Han, Y.E. Na \& K.K. Kang (2009). Biodiversity of Fauna and Flora in Korean Paddy Field. $<$ http://www.niaes.affrc.go.jp/marco/marco2009/english/ program/WS4-02_Bang_Hea-son-KR.pdf> downloaded on 13 September 2010.

Cheung, K.W. (2008). Spatial and seasonal variations of freshwater macroinvertebrates, Odonata and waterbirds in Luk Keng Marshland, Hong Kong. MPhil Thesis, Department of Zoology, University of Hong Kong.

Cho, D.O. (2007). The evolution and resolution of conflicts on Saemangeum Reclamation Project. Ocean \& Coastal Management 50(11-12): 930-944.

Glotzhober, R.C. \& D. Riggs (1998). Adapting the Townes Malaise trap for collecting live Odonata. Bulletin of American Odonatology 5(3): 43-48.

ISME (International Society of Mangrove Ecology) (2010). What are Mangroves? <http://www.mangrove.or.jp/ mangrove/whats_mangrove.html $>$ Downloaded on 13 September 2010.

Iwata, S. \& M. Watanabe (2009). Spatial distribution and species composition of larval odonata in the artificial reed community established as a habitat for Mortonagrion hirosei Ashina (Zygoptera: Coenagrionidae). Odonatologica 38(4): 307-319.

Lee, S.Y. (2002). Venturing Forest in the Water. Friends of the Country Parks. Hong Kong, 11-13pp.

Lin, Y.F. \& H. Chen (eds.) (2006). Conservationists amazed at 
endangered damselfly discovery. International Conservation Newsletter - Society for Wildlife and Nature 14(2): 5-6.

Matsu'ura, S. \& M. Watanabe (2006). The conservation ecology of the brackish water damselfly, Mortonagrion hirosei - Fecundity and oviposition in four coexisting damselfly species in estuarine habitat. The Seveenteenth International Symposium of Odonatology: 34.

Mimura, Y. \& M. Watanabe (2006). The conservation ecology of the brackish water damselfly, Mortonagrion hirosei - population dynamics of adults in the original habitat. Abstract of Papers. The Seventeenth International Symposium of Odonatology: 36.

Ni, J. \& H. Qin (2003). Assessment of reclamation impact on inter-tidal habitat loss. Acta Scientiae Circumstantiae 23(3): 345-349.

Reels, G.T. (1994). Management strategies for the reed Phragmites australis (Cav.) Steud. at Mai Po Marshes Nature Reserve, Hong Kong, with observations on the associated insect fauna. MPhil Thesis, Department of Zoology, University of Hong Kong.

Tam, T.W., B.S.P., Kwan, K.K.Y. Wu, B.S.F. Wong, S.S.H. Tang, C.H.L. Fung, W.S.Y. Wong, J.K. Wong, S.W.L. Fong \& A.H.C. Lei (2008). Current status of dragonflies (Odonata) and their representation in protected areas of Hong Kong. Hong Kong Biodiversity 16: 1-7.

Teramoto, Y. \& M. Watanabe (2009). Colonization process of the threatened damselfly Mortonagrion hirosei, in the artificially established reed community. The 6th Asia-Pacific Congress of Entomology (APCE2009), Beijing, China.

Watanabe, M. (2007). Changes in spatial distribution and species composition of larval dragonflies in the artificial reed community established as a habitat for Mortonagrion hirosei, an endangered brackish water damselfly. 5th WDA International Symposium of Odonatology, Swakopmund, Namibia.

Watanabe, M. \& Y. Mimura (2003). Population dynamics of Mortonagrion hirosei (Odonata: Coenagrionidae). International Journal of Odonatology 6(1): 65-78.
Watanabe, M. \& Y. Mimura (2004). Diurnal changes in perching sites and low mobility of adult Mortonagrion hirosei Asahina inhabiting understorey of dense reed community (Zygoptera: Coenagrionidae). Odonatologica 33(3): 303-313.

Watanabe, M., S. Matsu'ura \& M. Fukaya (2008). Changes in distribution and abundance of the endangered damselfly Mortonagrion hirosei Asahina(Zygoptera: Coemagrionidae) in a reed community artificially established for its conservation. Journal of Insect Conservation 12: 663-670.

Wilson, K. (1994). Hong Kong Dragonfly Update. Porcupine! 10: 4 .

Wilson, K.D.P. (1995). Hong Kong Dragonflies. Urban Council, Hong Kong, 58-59pp.

Wilson, K.D.P. (1997). An annotated checklist of the Hong Kong dragonflies with recommendations for their conservation. Memoirs of the Hong Kong Natural History Society 21: 1-68.

Wilson, K.D.P. (2004). Field Guide to the Dragonflies of Hong Kong. Second Edition. Hong Kong, Agriculture, Fisheries and Conservation Department, 142-143pp.

Wilson, K. (2006). Mortonagrion hirosei. In: IUCN 2010. IUCN Red List of Threatened Species. Version 2010.3. $<$ www.iucnredlist.org $>$. Downloaded on 14 September 2010.

Wilson, K.D.P. \& G. Reels (2011). Mortonagrion hirosei. In: IUCN 2011. IUCN Red List of Threatened Species. Version 2011.1. <www.iucnredlist.org>. Downloaded on 10 July 2011.

WWF-HK (2006). An extension to the existing boardwalk and new floating Mudflat Bird-watching hide at Mai Po nature reserve for education and conservation purposes. Project Profile to HKSAR Government.

WWF-HK (2010). Mai Po Wildlife Factsheet. Invertebrates Species of Interest. Four-spot Midget Mortonagrion hirosei. Downloaded from [http://assets.wwf.org.hk/downloads/ four_spot_midget.pdf] on 13 September 2010. 